\title{
A XVII. század Semmelweise, avagy Jean Baptiste Denis és az első, emberbe történt vérátömlesztés (1667)
}

\author{
Kiss László dr.
}

Orvostörténeti alaptény, hogy emberen az első vérátömlesztést a francia Jean Baptiste Denis (1635?-1704) hajtotta végre 1667. június 15-én [1: 122]. Az eseményről a Medical Journalists' Association elnöke, az angol(!) Pete Moore adott ki oknyomozó könyvet 2003-ban „Blood and Justice” (Vér és igazság) címmel. Moore könyve részletesen tudósít az előzményekről is: Angliában 1665 óta kísérletezik az orvos Richard Lower (1631-1691) és a lelkész John Wilkins (1614-1672) vérátömlesztéssel. Az „ötletgazda” egyébként egy anglikán pap, Francis Potter (1594-1674) - a vérkeringést leíró W. Harvey barátja - volt. Potter a ma is legkedveltebb latin költő, Ovidius (Kr. e. 43-Kr. u. 17/18) Medea című tragédiájából „lopta” az ötletet [1: 62]. Az argonauta Iaszón atyjának Medea (Médeia) úgy adja vissza fiatalságát, hogy miközben varázsitalt önt a szájába, eret vág a nyakán. Ma már nem csak legenda, hogy a kolkhiszi királylány, Medea szépségén kívül bölcsességéről és az orvosi tudományban való jártasságáról is híres volt [2]. A maga korában különcnek számító, kísérletező, teológiai kérdéseken tépelődő Pottert elgondolkoztatja Medea „fiatalító” kísérletének vért lebocsátó mozzanata: Lehetséges az öreg és „fáradt” vért fiatalra, életerősre cserélni? 1652-ben tyúkokon próbált vérátömlesztést, nem sok sikerrel.

Potter ötletét végül is Lower viszi sikerre 1666 februárjában. Kísérletéről így számol be: „Kiválasztottam egy közepes nagyságú kutyát, s miután lekötöztem, kiengedtem összes vérét. A kutya előbb hangosan ugatott, de csakhamar erejét vesztette, görcsöket kapott és rángatódzni kezdett. Hogy felélesszem ebből a hatalmas vérveszteségből, melléje kötöttem egy másik kutyát, a nyaki artériájába csövet vezettem és a cső másik végét a kisebb kutya vénájába nyomtam. A kisebb kutya azonnal visszanyerte eszméletét és megpróbált kiszabadulni. Lehet, hogy túl sok vért adtam neki. Lekötöttem a nagyobb kutya verőerét, hogy elállítsam a vérzést, és újra vért enged- tem ki a kisebb kutyából, majd azonnal pótoltam is egy másik nagy kutya vérével. Aztán lekötöttem a kis kutya nyaki vénáját, eltávolítottam a láncokat, melyekkel lekötöztem volt és figyeltem, mi fog történni. A kutya leugrott az asztalról és úgy tûnt, semmi baja. Gazdájához futott és a fúben hempergett, hogy letörölje magáról a vért. Valószínúleg semmivel sem szenvedett többet, mintha valaki bedobta volna a patakba" [1: 97].

Az Oxfordban, a helyi értelmiségi elit meghívott tagjai előtt zajló kísérlet sikerének titkáról Lower az 1669-ben megjelent Tractatus de Corde, item de motu et colore sanguinis címú könyvében így vélekedik: „Az újabb kísérletem sikeresebb volt. Úgy döntöttem, megpróbálom hüebben utánozni a természetet. A természet a vért az artériákból a vénákba hajtja, és ezért az egyik állat verőerének a másik állat vénájának összekötésével egyszerün meghosszabbodik az első állat vérkeringése" [1:96].

Moore szerint ma már megállapíthatatlan, mi vezette a filozófia és matematika párizsi professzorát, Denist (Denyst) arra, hogy hátat fordítson a számok világának. Moore szerint Denis teológiai tanulmányai után Montpellier-ben orvostudományt is hallgatott, de doktori címet matematikából szerzett [1: 29]. Amit biztosan tudunk: 1667 márciusának elején értekezést írt a vérátömlesztéssel szerzett tapasztalatairól. Értekezése egy hét(!) múlva megjelent az 1665-ben alapított Journal des Scavans párizsi lap hasábjain. Írásából kiderült, hogy „a tehetséges sebész és anatómus”, Paul Emmerey (?-1690) barátjával többször végzett sikeres vérátömlesztést kutyákon. Sơt borjú vérét is ömlesztette kutyába, hogy megtudja, mi történik akkor, ha kisebb állat vére nagyobb állat vérével keveredik. Nem észlelt változást a kutya viselkedésében. Javított a technikán is: az érvágás helyett a „csövet” a bőrön át tolta az érbe.

Ilyen előzmények után került sor az első, emberbe történő vérátömlesztésre Párizsban, 1667. június 15-én. Egy 15-16 év körüli ifjú volt a kísérlet alanya. Két hónap-

Az Orvosi Hetilap alapításának 160. évében a Szerkesztőség felkérésére készített tanulmány. 
ja „lázban” szenvedett. A lázat abban az időben úgy értelmezték, hogy a test „humorjai” - vér, epe, fekete epe, nyák - nincsenek egyensúlyban: a testben túl sok vér van, amely meleget (lázat) termel. E logika szerint a fó gyógymód a vérmennyiség csökkentése. Két hónap alatt húszszor vágtak eret a betegen. A beteg azonban egyre gyengébb, egyre „álmosabb” lett. Egyetérthetünk Moore-ral: már nem is a betegségétől, hanem a gyógymódtól érezte magát egyre rosszabbul.

Denis és Emmerey úgy vélte, hogy a beteg testében kevés a vér, és ami van, az tele van „keserüséggel”. A kevés vér kevés belső meleget termel és a vér nem áramlik, hanem inkább áll az erekben. Amikor eret vágtak: a vér „sötét és sưrú volt és alig folyt” [1: 123]. Az orvostudomány egyik mérföldkövének tekinthető kísérlet hajnali ötkor kezdődött. Elsőként Denis eret vágott a fiún és kifolyatott 3 uncia - körülbelül 90 gramm - vért, hogy „helyet csináljon az új vérnek” [1: 124]. Emmerey csövet szúrt egy bárány nyaki artériájába, majd a csô másik végét a fiú felső végtagjának vénájába szúrta. A kiengedett vérmennyiség mintegy háromszorosát - tehát megközelítóleg 270 gramm - vért ömlesztettek át. Ezzel vélték - pótolták a vérveszteséget, hígították a vér „keserúségét” és elegendő „életadó meleget” termelő vért juttattak be a fiú testébe.

A fiú jól érezte magát, a mútét alatt forróságot érzett a karjában. Tíz órától már talpon volt, megjött az étvágya. Előző nap megütötte az oldalát, a fájdalom a vérátömlesztés után elmúlt. Orvosai ebből arra következtettek, hogy vérátömlesztéssel nemcsak a lázat, hanem a fájdalmat is lehet gyógyítani. Délután négy körül enyhe orrvérzés jelentkezett. - Denis ennek okát abban látta, hogy mégis csak túl sok vért adott be és a test így szabadul meg a feleslegtól. A további napok sem hoztak roszszabbodást, sőt! Egyre javult az étvágy, a fiú hízni kezdett, jól aludt és már nem fáradt el semmilyen munkában. Denis - nyilván, hogy továbbra is szemmel tarthassa állapotát - szolgaként a házába fogadja az első vérátömlesztés alanyát.

Moore szerint az állatból emberbe végzett transzfúzió után bekövetkezett állapotjavulás inkább magyarázható az érvágások beszüntetésével - lázas betegsége előtt a fiú egészséges volt -, mint a vérátömlesztés hatásával. Az orrvérzés a bárányvérre való védekezőreakcióként értékelhető, amely azonban nem volt elég erős ahhoz, hogy tartós egészségkárosodást váltson ki [1: 125].

Figyelemre méltó, hogy Denis egyszer sem nevezi meg kísérlete alanyát - amint azt E. Jenner megteszi majd 1796-ban, a hasonlóan kockázatos első vakcináció $($ vacca $=$ tehén $)$ azaz a tehénhimlőhólyagokból vett nyirok emberbe történt beoltásának végzésekor.

A vérátömlesztés hőskorát tárgyaló dolgozatok általában itt be is fejezik Denis „történetét” - ha egyáltalán tudnak róla -, holott az ezt követó események is nem kevés tanulságot tartalmaznak. Denis egyértelmúen sikernek könyvelte el a vérátömlesztést és ezért elfogadta a kor híres mecénásának, az 1657-ben tudományos akadé- miát - Académie Montmor - alapított Henri de Montmor (1600?-1679) ajánlatát [1: 31]. Montmor befogadott palotájába egy 34 éves szolgát, aki évek óta "ôrültségi rohamokban" szenved: a roham idején agreszszív, meztelenül futkos Párizs utcáin és gyújtogat. Montmor tudta, hogy „akadémiájának” két tagja, Denis és Emmerey kísérleteket végez az állati vér emberbe ömlesztésével. Tudta azt is, hogy a vér a lélek lakóhelye. Nem lehetne tehát Antoine Mauroy - így hívták a lelki beteg szolgát - búnös, rossz vérét kicserélni egy szelíd állat, például bárány vérére? Denisék alaposan megvizsgálták a szolgát, úgy találták, hogy testileg egészséges, csupán a „lelke”, azaz a vére beteg - ideális alany a vérátömlesztésre.

Az újabb „gyógyítói” kísérletre 1667. december 19én kerül sor, Denis párizsi lakásán. Hogy elegendő vér álljon rendelkezésükre, bárány helyett borjút választottak „donornak”. Ismét „helycsinálással”, azaz érvágással kezdtek, majd - a felhasznált idő szerint saccolva - körülbelül öt-hat uncia borjúvért folyattak Mauroy vénájába. Tízunciányit terveztek, ám Mauroy elájult, így befejezték a kísérletet. Amikor a szolga magához tért, enni kért, s bár az éjszakát „énekléssel, fütyüléssel s egyéb szertelenségekkel" töltötte, Denisnek reggel úgy tűnt, hogy "nyugodtabb, sôt hallgatag” [1: 176]. Ezért a teljes siker érdekében a vérátömlesztést már 21 -én megismételték. Most körülbelül egy libra - azaz mintegy 327 gramm ( 1 libra $=12$ uncia) - vért ömlesztettek át, nem várt következménnyel. Mauroy erős fájdalmat érzett a borjúvért fogadó karjában, izzadni, majd hányni kezdett. Ágyéka táján erős fájdalmat jelzett, majd - Denisék és a nézőközönség megdöbbenésére - vizeletet ürített, amely „olyan fekete volt, mint a korom” [1: 177]. Éjszaka viszont már nyugodtan aludt, amit Denis a gyógyulás jelének tekintett. Egy másik ,jel” is a gyógyulás mellett szólt: tekintettel a közelgő karácsonyra, Mauroy papot kért. 23-án azonban az orra kezdett vérezni, s továbbra is „sötét” színű volt a vizelete.

Karácsony napján megáldozott, és az abbé „lelkileg” egészségesnek nyilvánította ôt. Moore megjegyzi: Denis nem kívánhatott nyomósabb bizonyítékot - íme, az egyház és Isten szolgája igazolja, hogy az őrült meggyógyult [1: 178]. A bonyodalom ez után kezdődött: előkerült Mauroy felesége és Denis tiltakozása ellenére hazavitte az „egészséges” férjét. Otthon - a doktorok tiltása ellenére - tojással és levesekkel „erősítette” oót, ami - Denistől tudjuk - ismét felhevítette a vérét. Sốt szexuális aktusra csábította férjét, ami a kor felfogása szerint „még jobban felhevíti a vért". Rövidre zárva: Mauroy újra beteg lett. Most a feleség könyörög Denisnek, hogy egy újabb vérátömlesztéssel tegye újra egészségessé férjét. Denis nem áll kötélnek, de a lelkes feleség ráveszi Emmereyt, hogy kezdje meg az átömlesztést. Denis tiltakozik, ám végül enged. Érvágással kezdenek, de a beteg reszketni kezd és a lábfejen ejtett vágásból egyre kevesebb vér folyik. $S$ bár az átömlesztést abbahagyják, Mauroy nem éri meg a reggelt... 
Az ügy 1668. április 17-én a bíróságon folytatódik. A vád súlyos: Denis - az orvosi kar tudós tagjai ellenzését figyelmen kívül hagyva - borjú vérét ömlesztette át egy betegbe. A harmadik kísérletet követóen a beteg meghalt, ergo Denis megölte Mauroyt [1: 221]. Boncolás nem történt, mert a feleség sietve eltemettette férje holttestét. Denis és védóje azonban tudták, mi, illetve kik állnak a keresetet benyújtó özvegy mögött. A montpellier-i orvosi képzésre mindig is féltékenykedő és a vérátömlesztés gondolatát eleve elvetô párizsi fakultás három orvosa heccelte fel az özvegyet - pénzzel is támogatva őt - a Denis elleni fellépésre. Ismét rövidre zárom a történetét, amely akár Denis halálos ítéletével is végző́dhetett volna, ha nem „kerül elő” egy szemtanú. Mauroyék szomszédasszonya eskü alatt vallotta, hogy a feleség egy kiadós veszekedés után, a harmadik, félbehagyott vérátömlesztési kísérlet estéjén, „gyanús” vacsorát adott férjének. A vacsora maradékát felfaló macska még aznap éjjel elpusztult. D'Omesson bíró hitelt adott a szomszédaszszony szavainak és felmentette Denist a gyilkosság vádja alól...

Moore szavaival: Denis csatát nyert, de háborút vesztett. Mert a bírói ítélet így folytatódott: a jövőben a párizsi orvosi kar beleegyezése nélkül nem lehet vért átömleszteni emberbe. Az ítélet Franciaország egész területére vonatkozott. A csalódott Denis abban reménykedik, hogy a fakultás ismét elhamarkodott döntést hozott, mint az antimon esetében. A párizsi fakultás az antimont is méregnek nyilvánította - a többi orvosi karral ellentétben -, ám amikor a királyt, XIV. Lajost 1658ban az antimon gyógyította meg, visszakozni volt kénytelen. Az antimonper részleteit lásd Benedek könyvének "Az antimonháború" címú fejezetében [3: 242-250].

Sajnos, Denis reménykedése hiábavaló volt - a „transzfúzióháború" számára vereséggel végződött. 1675-ben a 85 éves X. Kelemen pápa (trónon: 1670-1676) betiltja a vérátömlesztési kísérleteket, három évvel később ugyanígy tesz az angol parlament is [1:234]. Moore szerint e tiltások tudománytörténeti értéke „úttörő” jellegükben rejlik: olyan moratóriumok ezek, amelyeket a hatalom/ politika a tudományos kutatás bizonyos területeire hirdet meg. A törvényhozók nem képesek megítélni a tárgyalt téma valódi értékét, ezért döntésüket az orvosi közösségek véleményére alapozzák. E probléma ma is él, lásd a klónozás, a genetikailag manipulált élelmiszerek, az eutanázia stb. eseteit.

A szerencsére felmentéssel végződött bírósági per nem az első „pofon” volt, amit Denisnek sikere csúcsán el kellett viselnie. Kísérleteinek egyik mozgatórúgója erôs ambíciója volt: úgy vélte, ha első́ként ömleszt át vért emberbe, ezzel nevét örökbe beírja a történelembe [1:34]. Az első transzfúziót követô hónapokban úgy nézett ki, hogy elsőbbségét még a nagy vetélytársak, a vérkeringést felfedező Harvey hazájának orvosai is elismerik. Erre utalt az Angliában élő német emigráns, Henry Oldenburg (16191677) által 1665-től kiadott Philosophical Transactions lap 27. számában megjelent közlemény. A lap Denisnek mecénásához, Montmorhoz írt francia levelének angol fordítását közölte: „A letter concerning a new way of curing sundry diseases by transfusion of blood, written to Monsieur de Montmor, Counsellor to the French King, and master of request. By J: Denis Professor of philosophy and mathematicks" [1: 247].

Már a közlemény kezdő sorai melengették Denis becsvágyát: tíz éve annak, hogy a Montmor-akadémia tudós vitáiban szóba került a vérátömlesztés gondolata, Denist azóta foglalkoztatta ennek az ötletnek a megvalósítása. A cikk a továbbiakban leírja az 1667. június 15-én végzett első, majd később - egy egészséges 45 éves munkáson - megismételt transzfúziót. Denis méltán eufóriás: a londoni Royal Society titkára, Oldenburg lapjában megjelent elismerés megnyithatja számára az utat nemcsak a világhír, de a francia Académie Royale des Sciences tagsága felé is. Amikor ugyanis a Montmor Akadémia helyébe 1667 elején „a tudományok királyi társasága” lépett, Denist nem vette fel tagjai közé. Ha most megválasztják őt, ez nemcsak becsvágyának, hanem anyagi helyzetének is jót tett volna. A francia „királyi társaság” tagja ugyanis fizetést kapott - a pár évvel korábban alakult londoniban a tagok járultak hozzá a társaság múködtetéséhez [1: 92].

Denis eufóriája azonban csak rövid ideig tartott. 1667 augusztusában Oldenburg bevonta a 27. számot - amelynek megjelenése alatt vizsgálati fogságban ült a Towerben kémkedés vádjával $-\mathrm{s}$ az újranyomtatott 27. számban a terjedelmes Montmor-levél helyett egy rövid tudósítást tett közzé. Ebben vitát nem tứrő hangon leszögezi, hogy a transzfúzió gondolatával nem a franciák, hanem az angolok rukkoltak elő és a győzelem e téren a Lower-King angol kettőst illeti meg. Edmund King (1629-1709) londoni orvos 1667-ben ismételten próbálkozott vérátömlesztéssel borjúból bárányba, bárányból kutyába, sôt bárányból rókába [1: 112, 114]. S hogy teljes legyen Denis „kijózanítása”, a Philosophical Transactions 28. számában hosszú értekezést közöl a vérátömlesztésről: „Of more trials of transfusion accompanied with some considerations thereon, chiefly in reference to its circumspect practice on man; together with a farther vindication of this invention from ussurpers" [1: 247248].

A tanulmány nemcsak kritizálta Denist, hanem rafinált módon kétségbe vonta elsőbbségét is. „Amíg készségesen elismerjük, hogy elsók voltak - értsd a franciák K. L. -, bátorkodunk értesíteni a világot, hogy az angol kutatók ezt a beavatkozást emberen már régen kipróbálták volna, ha nem féltek volna annyira az emberi élet kockáztatásától...” Ez nem azt jelenti, hogy nem foglalkoznak a gondolattal. A kiadó már pár hónappal ezelőtt a saját szemeivel látta az ehhez előkészített múszereket... További bizonyítékként közli a módszer leírását dr. Edmund Kingnek a kiadóhoz írt leveléből. Ez az igazi elsőség, mivel monsieuer Denis (Denis úr) nem tartotta fontosnak leírni módszerét, amelyet Franciaországban az emberen alkalmaztak... [1: 135-136]. 
E sajtóbeli kioktatást követte 1668-ban a már tárgyalt per, amely Denist gyilkossággal vádolta. S mint említettem, e „csatát” Denis megnyerte, ám már nem maradt ereje a „háború” folytatására. Figyelme ismét a matematika, filozófia és asztronómia felé fordul. Amikor 1673ban az angol király, II. Károly meghívja őt, hogy számoljon be a vérátömlesztéssel szerzett tapasztalatairól, Denis már nem a fáradhatatlanul újat kereső kutató [1: 235]. Aránylag fiatalon, 1704-ben hunyt el. A vérátömlesztés gondolata már csak búvópatakként tör fel időnként a tudomány felszínére, egészen 1825-ig. Ekkor egy angol szülész, James Blundell (1790-1877) emberből emberbe való átömlesztéssel próbálja megmenteni az erôsen kivérzett szülőnők életét - nem teljesen sikertelenül [4].

Talán nem felesleges megemlíteni, hogy az angolok máig nem „igyekeznek” elismerni Denis prioritását. A jeles angol orvostörténész, Roy Porter (1946-2001) magyarul is megjelent könyvében például ez olvasható: „Harvey angol követői közül ... Richard Lower ... azzal is halhatatlanná tette a nevét, hogy ő végezte az első vértranszfúziót. A múveletet először kutyáról kutyára, majd emberből emberre hajtotta végre" [5]. Nem tudjuk, Porter tekintélye vagy a lektorok, fordítók figyelmetlensége okozta-e, hogy e pontatlanságot már 1997 ben leírhatta Porter, a több nyelvre lefordított monumentális, nyolcszáz oldalas orvostörténeti kézikönyvében. Én a könyv 2001-ben, cseh nyelven kiadott változatából idézem az ominózus sorokat: „A XVII. század ötvenes éveinek végén ... a francia orvos, Jean-Baptiste Denys (1625-1704) vérátömlesztést végzett kutyából kutyába. Leghíresebbé azonban a bárányvér emberbe való ömlesztése vált, amelyet 1667 novemberében a Királyi Társaság tagjainak szeme láttára Richard Lower végzett; az állat vérét egyenesen annak a teológiát tanuló Arthur Coga vérkeringésébe transzfundálta, akit egy kicsit ütődöttnek tartottak, és akit a transzfúzió ettől a zavartól volt hivatva megszabadítani” [6: 265].

Szegény Denis - foroghat a sírjában... E sorok írójának pedig óhatatlanul a mi Semmelweisünk sorsa jut eszébe: az ő prioritását sokan még ma is kétségbe vonják. A gyermekágyi lázzal kapcsolatban a most emlegetett Porter például így kerüli meg Semmelweis prioritásának elismerését: „Már Alexander Gordon ... arra a következtetésre jutott 1795-ben, hogy ezt a betegséget valami- lyen bomló anyag okozza, amelyet a méhbe a szülés során vagy a bába, vagy az orvos visz be. Ennek megakadályozására alapos (kéz)mosást ajánl. A Bostonban múködő Oliver Wendel Holmes (1809-1894) szintén ... fertőző betegségnek tartotta a gyermekágyi lázat, amelynek csíráit azoknak kell átvinnie, akik a szülésnél asszisztálnak. Ezért ajánlotta, hogy ... klóros vízben mossanak kezet" [6: 409].

Semmelweis születésének közelgő 200. évfordulója és Denis úttörő lépésének, az első, emberbe történt vérátömlesztésnek 350. évfordulója jó alkalom arra, hogy elgondolkozzunk: mennyire hiteles az, amit nagy elődeinkről tudunk és továbbadunk.

\section{Irodalom}

[1] Moore P. Blood and justice. John Wiley and Sons Ltd, England, 2003. Transl. in Czech: Knišová K. Krev a spravedlnost. CENTA, Brno, 2005.

[2] Shengelia R, Khelaia N, Bibileishvili L. Ancient black sea countries and medicine. In: 40th International Congress on the History of Medicine. August 26-30, 2006, Budapest - Hungary. Proceedings I. pp. 325-329.

[3] Benedek I. Hygieia. History of European medicine with the biographies of outstanding doctors. Ancient times, middle ages, beginning of modern times. [Hügieia. Az európai orvostudomány története jelesebb doktorok életrajzával. Ókor, középkor, reneszánsz, újkor kezdete.] Gondolat Kiadó, Budapest, 1990. [Hungarian]

[4] Genschorek W. Pioneers of surgery. Johann Friedrich Dieffenbach, Theodor Billroth. [Wegbereiter der Chirurgie. Johann Friedrich Dieffenbach, Theodor Billroth.] S. Hirzel Verlag, Leipzig, 1983; p. 47. [German]

[5] Porter R. Blood and guts. A short history of medicine. Allen Lane, The Penguin Press, 2002. Transl. in Hungarian: Szabó M. Vér és virtus. Az orvostudomány rövid története. HVG Kiadó, Budapest, 2003; p. 86.

[6] Porter R. The greatest benefit to mankind: a medical history of humanity from antiquity to the present, London, 1997. Transl. in Czech: Hořejší J. Největší dobrodiní lidstva. Historie medicíny od starověku po současnost. Prostor, Praha, 2001.

(Kiss László dr., SK-93 008 Csilizradvány 284., Szlovákia e-mail: kiss.agi@panelnet.sk)

Az Orvosi Hetilap egyes számai megvásárolhatók a Mediprint Orvosi Könyvesboltban. Cím: Budapest V., Múzeum krt. 17. - Telefon: 317-4948 